\title{
Factors Influencing the Perception of the Selling Price of Luxury Apartments
}

\author{
Huu Cuong NGUYEN ${ }^{1}$, Duc Tai DO ${ }^{2}$
}

Received: March 03, 2020 Revised: March 15, 2020 Accepted: April 03, 2020

\begin{abstract}
The study aims to identify and measure factors affecting the perception of the selling price of luxury apartments in Hanoi. We conducted a questionnaire consisting of 29 observation variables with a 5-point Likert scale. Independent variables were measured from 1 "without effect" to 5 "strongly". Based on the desk review and results of interviews, a total of 500 questionnaires were sent to research participants for collection; 458 of them met standard and were subject to be analyzed. This study employs Cronbach's Alpha test, and regression model. The results of Exploratory Factor Analysis (EFA) and Multiple Regression Analysis (MRA) identify five main determinants influencing the perception of the selling price of luxury apartments in Hanoi, including Physical characteristics of a luxury apartment (PC); Location and position of an apartment (LP); Surrounding Area (SA); Quality of service provided by managers; (QS) and Demographics factor (DF). Based on the findings, some recommendations have been proposed to help the firm leaders design appropriate personnel policies for creating better price satisfaction for customers in the future. On this basis, the authors propose a number of recommendations to improve the quality of luxury apartments, thereby contributing to the development of the market for luxury apartments in Hanoi.
\end{abstract}

Keywords : Selling Price, Selling Price Perception, Luxury Apartments, Real Estate, Hanoi, Vietnam

JEL Classification Code: G12, G13, G14, L80, L85

\section{Introduction}

The real estate market plays an important role in the economy of all countries in the world. Not only does it ensure the construction of the necessary infrastructure for working and living condition, this market also has a strong impact on the development of the economy. The selling price of luxury apartment segment (LAS) is an indication of economic growth, rapid urbanization and LAS is becoming preference of high-income earners segment with high quality of life.

\footnotetext{
${ }^{1}$ First Author. PhD Candidate, The National Economics University, Vietnam / VITC Joint Stock Company / Chairman, Hanoi Real Estate Club, Vietnam. Email: cuong333hanoi@gmail.com

${ }^{2}$ Corresponding Author. Lecturer, Department of Accounting, University of Labor and Social Affairs, Vietnam [Postal Address: No. 43, Tran Duy Hung Road, Cau Giay District, Hanoi, 113000, Vietnam] Email: taiketoanquocte@gmail.com

(c) Copyright: The Author(s)

This is an Open Access article distributed under the terms of the Creative Commons Attribution Non-Commercial License (http://Creativecommons.org/licenses/by-nc/4.0/) which permits unrestricted noncommercial use, distribution, and reproduction in any medium, provided the original work is properly cited.
}

The demand for housing in big cities is increasing and diverse due to many reasons. Firstly, the population is growing faster and the trend of migration from suburban areas to big cities like Hanoi and Ho Chi Minh City are increasing. Secondly, the younger generation now prefers separating from their parents. The demographic division, the need to move out when getting married, and the trend of moving to the center, lead to high demand for housing while the city land bank is increasingly tight. Third, expatriates, businesses and foreign organizations are returning home for working, doing business and living in Hanoi and Ho Chi Minh City. At the same time, many new urban areas and many industrial zones along the inner city need a large amount of concentrated labor. Moreover, the demand for land for housing and public services are increasingly urgent.

Housing is not only a place for people to live, but affects their morale, quality of life and economic development also. Urban areas with adequate conditions and amenities will directly or indirectly help people develop and improve their quality of life. Those who strive to own and prioritize housing quality have many opportunities to access high quality services such as education and health. 
Most high-end apartments have integrated material and spiritual elements, meeting the diverse needs of highincome households. The buildings are arranged with many different functions, combining the purpose of living and doing business, etc. However, in reality, not all luxury apartments promise that potential for investment. There are also a number of high-end apartment projects, but after a few years in operation, they have revealed their low quality and decrease in value, causing confusion for buyers. Besides, most high-end apartment projects in Hanoi are at quite high prices, etc.

According to the above reasons, studying the factors affecting the selling price of luxury apartments in Hanoi is a practical and necessary approach.

\section{Literature Review}

Studies in the world related to research topics: the location of real estate is the main factor affecting property prices (Vukina \& Wossink, 2000). Sergio, Jorge, and Bernardo (2002) used the Hedonic model, built 20 observation variables and research models. The research results show that air quality has an influence on the value of apartments, the closer the apartment is to the water treatment plant, the less valuable the apartment is.

Özdilek, Canonne, and Besner (2009) suggest that three groups of factors affecting real estate prices are: (i) physical variables, (ii) ambient variables, and (iii) location variables.

Real-estate prices and real-estate credit are correlated. When real-estate prices go up, real-estate credit goes up. In contrast, if real-estate credit increases, real-estate prices would not increase at the same rate (Gerlach \& Wensheng, 2005). Fanning (2005) stated that the best and optimal use of real-estate is using it for one of possible purposes, which are physically, financially and legally feasible.

Surrounding environment, social and physical factors all affect apartment prices (Kim, 2007). The authors pointed out a number of attributes such as: apartments that are near big roads or noisy and polluted places have reduced price, while the beauty and high socio-economic status of the surrounding environment increase apartment prices.

Selim (2008) conducted a study in Turkey, using the Hedonic regression model showing that house size, number of rooms, type of house, location characteristics and type of house are factors that affect house price.

Many authors have mentioned the surrounding factors affecting the selling price of apartments. Yusuf \& Resosudarmo (2009) argue that air quality has an influence on the choice of households in Indonesia, thereby affecting the price of their apartments. The author also pointed out that attributes such as $\mathrm{CO}, \mathrm{SO} 2$ pollution and lead pollution have a negative correlation. The author concludes, (i) good air quality has a positive effect on the price of apartments, buyers are willing to pay a higher price for apartments with good air quality; (ii) the selling price of the apartment is inversely proportional to the surrounding environment such as water pollution and noise. Wang and Li (2006) stated that buyers are willing to pay more for the apartment if the apartment's environment has a low crime rate and good security. Ghosh, Guttery, and Sirmans, (1997) suggest that apartment investors should consider security factors when developing projects and constructing apartments. Greenberg and Crossney (2006) asserted that the negative direction of the surrounding environment such as crime, low security and poor transportation reduced the value of apartments, thereby negatively affecting the price of apartments. Meanwhile, the positive direction of the surrounding environment such as good neighbors, good schools, good shopping areas will increase the quality of the surrounding environment, thereby positively affecting the price of the apartment.

The characteristics of the apartment that affect the perception of the selling price of the apartment are analyzed and measured. Hinkelman and Swidler (2008) confirm that Geographic location, shape and size of the apartment is related to depreciation calculation, thereby affecting the selling price of the apartment. Solomon, Bamossy, Akegaard, and Hogg (2006) suggest that consumer purchasing decisions are often based on an assessment of product quality or its brand. Research results by Qiuxue and James (2013) are quite similar to previous studies on the impact of real-estate characteristics (area, using time, etc) on real-estate prices. In addition, the author asserts that characteristics of luxury apartments are offered for sale in a completely different way from normal apartments are. These features include: area (a luxury apartment is about 2.5 times larger than a normal apartment), the height, width and length of the apartment, the number of bedrooms and bathrooms, equipment installed in the apartment, flooring types. On the other hand, the author also said that characteristics such as parking and the distance from the apartment to the city center, also affect the perception of the selling price of luxury apartments.

In addition, there have been studies related to this research topic, such as Seetharaman, Saravanan, Patwa, and Bey (2017) and Baek, Sim, and Lee (2019). Jeon (2018) studied the impact of economic policy uncertainty (EPU) of four Asian countries such as Korea, Japan, Hong Kong and China on housing market returns in Korea, and document the relationship between the (EPU) index of those four countries and the housing market including macroeconomic indicators in Korea. The EPU index of those four countries has a significantly negative effect on the housing purchase price index and housing lease price index in Korea.

In addition to international studies presented above, there are some other relevant studies in Vietnam, such as that of Nguyen, Bui, and Nguyen (2019) that showed that, (i) the 
real-estate market positively impacts Vietnam's economic growth, most noticeably in the second quarter lag and the fourth quarter lag, and then its trend impacts inversely, and (ii) the real-estate market and economic growth in Vietnam have fluctuated over time with many risks that are affected by the past shocks of these factors. Nguyen (2018) said that financial and non-financial factors have influence on customers' choice of buying low- or middle-priced houses. Bui (2013) uses position-quality theory to evaluate realestate prices. The authors conclude that the price of realestate in general and that of luxury apartments in particular are affected by two groups of factors: (i) factors reflecting housing quality, precinct area, number of floors and (ii) factors that reflect the location of the residence and distance to the city center. The study results also showed that the influence of factors on the price of real estate in general and that of luxury apartments in particular in descending order is as follows: Area of precinct, distance to city center; number of floors and housing location. Nguyen (2014) concludes, the factors that influence the decision to buy a luxury apartment are (i) the quality of apartment construction and apartment management service and (ii) customer support policies including preferential policies for customers and financial support of banks. These factors have a positive correlation to consumers' ability to afford.

The above studies focus on five factors that affect the perception of luxury apartments selling price in Hanoi, which are: Physical characteristics of a luxury apartment (PC); Location and position of an apartment (LP); Surrounding area (SA); Quality of service provided by managers (QS) and Demographics factor (DF). In the above studies, a number of studies are limited in research methods and research samples, etc. Thus, it can be affirmed that there has not been any comprehensive study about the influence of factors on the price of high-class apartments in Hanoi, Vietnam. This research inherits from previous studies and is developed with new component attributes of factors; it carries out research design, selects appropriate research methods to analyze, and valuates and measures the impact of factors on the price of high-class apartments in Hanoi. This study uses the survey method of price, so it is possible to view the selling price of luxury apartments as the perception of the selling price of the apartment.

\section{Theoretical Background}

\subsection{Theory of Planned Behavior}

The theory of proposed or planned behavior (TPB) of Ajzen (1991) is an extension of the theory of rational behavior (TRB) introduced and completed by Ajzen and Fishbein (1975) in 1980. This theory has a central element that is the intention of the individual to perform a certain act.
The intention of behavior is considered as the first element of behavior. The stronger the intention, the greater is the ability to perform the behavior. This will show how much people will try, to what extent or are still only in an attempt to perform a specific behavior. Intended behavioral theory has been adopted and widely used in studies with intentional as well as behavioral predictions.

Application of the theory to the study. The author wishes to retest a part of the theoretical model in the market of luxury apartments in Hanoi. Based on this theory, the author will add new factors, and the component properties of the factors affecting the perception of the price of luxury apartments. From there, it will measure the factors affecting the perception of the selling price of luxury apartments in Hanoi.

\subsection{Wealth Effect Theory}

Markowitz (1952), Kapopoulous and Siokis (2005) and others use wealth effect theory to analyze and apply it to real-estate and stock market. According to this theory, consumption is a function of income and total assets. Both income and total assets have a positive effect on spending. Total assets include stocks, bonds, real estate, etc. Because real estate is considered a consumer goods and an investment, so many consumers choose. According to Kapopoulous and Siokis (2005), the relationship between the stock market and real estate market shows the effect of assets due to the influence of investment portfolio adjustment. The authors argue that many companies increase their reinvestment in real estate, thereby increasing housing demand, and in turn, increasing demand for real estate. Finally, rising demand raises prices in the real estate market.

Application of the theory to the study. This theory is related to the Demographic factor affecting the selling price of apartments.

\subsection{The Position-Quality Theory}

The position-theory quality (Hoang \& Wakely, 2000) states that, when looking for a place to live, urban people always consider the choice between travel costs and housing costs; change in urban residential areas, can be conceived as including a simultaneous shift along two dimensions: housing position and housing quality.

Application of the theory to the study. This theory is related to the factors of the location of the apartment and the position of the apartment; the quality of services provided by management board affects the selling price of the apartment.

\section{Research Methodology}

The research process is conducted through two steps, including preliminary and final research. 
Step 1: We use both qualitative and quantitative research methodology for preliminary research.

Step 2: Official research is performed through running Cronbach's Alpha, EFA and regression model.

\subsection{The Preliminary Research}

\subsubsection{Qualitative Approach}

We interviewed three experts working as real-estate researchers and manager, and seven experts working as real-estate investors and traders in Hanoi; the experts are experienced in selling high-end apartments. The contents of the interviews are based on the draft scale includes five factors and 38 attributes (indicators). The results showed that experts identified that five factors and attributes (indicators) are appropriate, and do not add any more factors. Thus, this study has the draft scale includes five factors and 38 attributes (indicators), as below (see Table 1):

Table 1: Research variables

\begin{tabular}{|c|c|c|}
\hline Code & Variables & Sources \\
\hline \multicolumn{3}{|c|}{ Physical characteristics of a luxury apartment (PC) } \\
\hline PC1 & Textured area & \multirow{10}{*}{$\begin{array}{c}\text { Özdilek et al. } \\
\text { (2009); Wang \& } \\
\text { Li (2006); Zeng } \\
(2013)\end{array}$} \\
\hline PC2 & Physical lifespan & \\
\hline PC3 & $\begin{array}{l}\text { The number of apartments } \\
\text { on a floor }\end{array}$ & \\
\hline PC4 & $\begin{array}{l}\text { The size of kitchen, dining } \\
\text { room and living room }\end{array}$ & \\
\hline PC5 & $\begin{array}{l}\text { The number and size of } \\
\text { bedroom }\end{array}$ & \\
\hline PC6 & $\begin{array}{l}\text { The number and size of } \\
\text { bathroom }\end{array}$ & \\
\hline PC7 & Layout and decoration & \\
\hline PC8 & Architectural materials & \\
\hline PC9 & Methods of payment & \\
\hline PC10 & Legal nature & \\
\hline \multicolumn{3}{|c|}{ Surrounding area (SA) } \\
\hline SA1 & Garden in precinct & \multirow{9}{*}{$\begin{array}{c}\text { Cropper et. al } \\
\text { (1988); Sheppard } \\
\text { \& Cheshire } \\
\text { (1995); Zeng } \\
\text { (2013) }\end{array}$} \\
\hline SA2 & Surrounded by wall & \\
\hline SA3 & Air quality & \\
\hline SA4 & Noise & \\
\hline SA5 & Width of streets & \\
\hline SA6 & Green area & \\
\hline SA7 & $\begin{array}{l}\text { Rainwater drainage } \\
\text { system }\end{array}$ & \\
\hline SA8 & $\begin{array}{l}\text { Lighting system (on } \\
\text { streets) }\end{array}$ & \\
\hline SA9 & Pedestrian precinct & \\
\hline
\end{tabular}

\begin{tabular}{|c|c|c|}
\hline \multicolumn{3}{|c|}{ Location and position of an apartment (LP) } \\
\hline LP1 & $\begin{array}{l}\text { Distance to school and } \\
\text { kindergarten }\end{array}$ & \multirow{6}{*}{$\begin{array}{l}\text { Wang \& Li (2006); } \\
\text { Kuminoff et al. } \\
\text { (2008); Yusuf \& } \\
\text { Resosudarmo } \\
\text { (2009); Zeng } \\
\text { (2013) }\end{array}$} \\
\hline LP2 & $\begin{array}{l}\text { Distance to hospital and } \\
\text { clinic }\end{array}$ & \\
\hline LP3 & Distance to shopping mall & \\
\hline LP4 & $\begin{array}{l}\text { Distance to library, sport } \\
\text { area and welfare area }\end{array}$ & \\
\hline LP5 & $\begin{array}{l}\text { Located inside the city } \\
\text { (urban) }\end{array}$ & \\
\hline LP6 & Distance to workplace & \\
\hline \multicolumn{3}{|c|}{ Quality of service provided by managers (QS) } \\
\hline QS1 & $\begin{array}{l}\text { Providing services as } \\
\text { commitment }\end{array}$ & \multirow{7}{*}{$\begin{array}{l}\text { Kotler (2005); } \\
\text { Zeng (2013) }\end{array}$} \\
\hline QS2 & $\begin{array}{l}\text { Ability to meet and solve } \\
\text { buyers' issues }\end{array}$ & \\
\hline QS3 & $\begin{array}{l}\text { Create perception of price } \\
\text { for customers }\end{array}$ & \\
\hline QS4 & Polite attitude of staff & \\
\hline QS5 & $\begin{array}{l}\text { Respect the right of } \\
\text { customers }\end{array}$ & \\
\hline QS6 & $\begin{array}{l}\text { Convenient operating } \\
\text { hours }\end{array}$ & \\
\hline QS7 & Casual and polite dress & \\
\hline \multicolumn{3}{|c|}{ Demographics factor (DF) } \\
\hline DF1 & Gender & \multirow{6}{*}{ Zeng (2013) } \\
\hline DF2 & Age, social position & \\
\hline DF3 & Academic level & \\
\hline DF4 & Occupation & \\
\hline DF5 & Income & \\
\hline DF6 & The number of members & \\
\hline
\end{tabular}

\subsubsection{Quantitative Approach}

After having the draft scale table with five factors and 38 attributes, we designed a draft questionnaire. We then tested 130 subjects working at the field of real-estate in Hanoi, Vietnam. However, only 115 questionnaires were satisfactory and included in the analysis. Through convenient sampling methods to establish the model and official scales. Here are the following results:

In the Physical characteristics of a luxury apartment factor has the attribute "PC10" has Corrected Item - Total Correlation $<0.3$; so it is disqualified.

In the Location and position of an apartment has the attribute "LP5" has Corrected Item - Total Correlation $<0.3$; so it is disqualified. 
In the Surrounding area has the attributes "SA1, SA2, SA9" have Corrected Item - Total Correlation $<0.3$; so they are disqualified.

In the Quality of service provided by managers has the attributes "QS3, QS7" have Corrected Item - Total Correlation $<0.3$; so they are disqualified.

In the Demographics factor has the attributes "NK1, NK4" have Corrected Item - Total Correlation $<0.3$; so they are disqualified.

After that, we replayed the factors with the remaining attributes, the results show that Cronbach's Alpha $>0.6$ and Corrected Item - Total Correlation $>0.3$, therefore, it meets the demand.

We use SPSS 22 for analysis to determine the reliability through Cronbach's Alpha. The final result is five factors and 29 attributes that gain reliability. Thus, the official model and scale of this study include five factors and 29 attributes.

\subsection{The Final Research}

\subsubsection{Hypotheses}

H1: Physical characteristics of a luxury apartment has a positive influence on the perception of the selling price of luxury apartments

H2: Surrounding area has a positive influence on the perception of the selling price of luxury apartments

H3: Location and position of an apartment has a positive influence on the perception of the selling price of luxury apartments

H4: Quality of service provided by managers has a positive influence on the perception of the selling price of luxury apartments

H5: Demographics factor has a positive influence on the perception of the selling price of luxury apartments

\subsubsection{Building a Scale}

We have designed a questionnaire consisting of 29 variables with a 5-point Likert scale from 1 "without effect" to 5 "Strongly". Dependent variable: "the perception of the selling price of luxury apartments" includes 3 attributes.

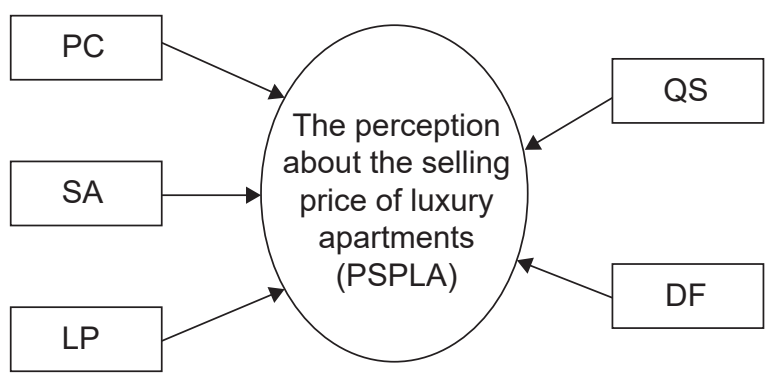

Figure 1: Research model

\subsubsection{Research Model}

We put forward research model in Figure 1.

\subsubsection{Sampling Method and Sample Size}

To achieve the objective, we used a random sample. The reason for choosing this method is because the respondents are easy to weigh; they are willing to answer the research questionnaire. Moreover, this method is less expensive in terms of time and cost to collect data.

According to Hair, Joseph, Anderson, Tatham, and Black (1998), the research sample must be at least five times the total number of indicators in the scales. The questionnaire of this study includes 29 indicators, therefore, the minimum sample size to achieve are 5 × $29=145$ observations.

\subsubsection{Description of Research Sample}

We sent 500 questionnaires directly to people working in real-estate in Hanoi; 471 responses were received. After checking the information on the returned questionnaires, there were 458 questionnaires with full information for data entry and analysis; the size of this sample was, thus, consistent with the study by Hair et al. (1998).

\section{Results}

\subsection{Descriptive Statistics}

Information on data collected are shown in Table 2. It shows that among the 458 respondents, 98 of them were 25 years old or younger, accounting for $21.4 \%$; 75 of them were over 36 years old; 175 of them were from 31 to 36 years old, accounting for $38.2 \%$, and $24.0 \%$ of the respondents were from 26 to 30 years old. Out of the 458 respondents, 192 had intermediate and college degrees, accounted for $41.9 \%$; and 195 had university degrees, accounted for $42.6 \%$. Holders of MA degrees accounted for $15.5 \%$. Besides, 127 participants had less than two years experience, accounted for $27.7 \%$; those with over three years experience accounted for $20.5 \%$, while the remaining 237 had from two to three years of experience.

\subsection{Results of Quality Scale Analysis}

Using scale analysis can eliminate inconsistent variables and reduce errors in the research model. Therefore, only variables with a total correlation coefficients (Corrected Item - Total Correlation) greater than 0.3 and Cronbach's Alpha coefficients equal or greater than 0.6 are accepted (Hair, Black, Babin, \& Anderson, 2009; Hoang \& Chu, 2008). Using Cronbach's Alpha analysis of determinants has 
Table 2: Respondent Characteristics

\begin{tabular}{|l|c|c|c|}
\hline & Frequency & Percent & $\begin{array}{c}\text { Cumulative } \\
\text { Percent }\end{array}$ \\
\hline Age \\
\hline Less 25 years old & 98 & 21.4 & 21.4 \\
\hline $\begin{array}{l}\text { From 26 to 30 } \\
\text { years old }\end{array}$ & 110 & 24.0 & 45.4 \\
\hline $\begin{array}{l}\text { From 31 to 36 } \\
\text { years old }\end{array}$ & 175 & 38.2 & 83.6 \\
\hline Over 36 years old & 75 & 16.4 & 100 \\
\hline Education level & 192 & 41.9 & 41.9 \\
\hline $\begin{array}{l}\text { Intermediate and } \\
\text { College }\end{array}$ & 195 & 42.6 & 84.5 \\
\hline University & 71 & 15.5 & 100 \\
\hline Master's (MA) & 458 & 100.0 & 100.0 \\
\hline Seniority work & 127 & 27.7 & 27.7 \\
\hline Less than 2 year & 94 & 20.5 & 48.2 \\
\hline Over 3 years & 237 & 51.8 & \\
\hline From 2 to 3 years & \multicolumn{5}{|l}{} \\
\hline Total & \multicolumn{4}{|l|}{} \\
\hline
\end{tabular}

Table 3: Results of Determinants Scales in the Model

\begin{tabular}{|l|c|c|c|}
\hline Determinants & $\mathbf{n}$ & $\begin{array}{c}\text { Cronbach's } \\
\text { Alpha }\end{array}$ & $\begin{array}{c}\text { Corrected } \\
\text { Item-Total } \\
\text { Correlation }\end{array}$ \\
\hline $\begin{array}{l}\text { Physical } \\
\text { characteristics of a } \\
\text { luxury apartment (PC) }\end{array}$ & 9 & 0.869 & 0.564 \\
\hline $\begin{array}{l}\text { Location and position } \\
\text { of an apartment (LP) }\end{array}$ & 5 & 0.865 & 0.655 \\
\hline Surrounding area (PC) & 6 & 0.833 & 0.482 \\
\hline $\begin{array}{l}\text { Quality of service } \\
\text { provided by managers } \\
\text { (QS) }\end{array}$ & 5 & 0.835 & 0.601 \\
\hline $\begin{array}{l}\text { Demographics factor } \\
\text { (DF) }\end{array}$ & 4 & 0.816 & 0.586 \\
\hline
\end{tabular}

Table 4: KMO and Bartlett's Test

\begin{tabular}{|l|c|c|}
\hline \multicolumn{2}{|c|}{$\begin{array}{c}\text { Kaiser-Meyer-Olkin Measure of } \\
\text { Sampling Adequacy. }\end{array}$} & .897 \\
\hline $\begin{array}{l}\text { Bartlett's Test of } \\
\text { Sphericity }\end{array}$ & Approx. Chi-Square & $5,601.009$ \\
\cline { 2 - 3 } & Df & 406 \\
\cline { 2 - 3 } & Sig. & 0.000 \\
\hline
\end{tabular}

shown their influence on the perception of the selling price of luxury apartments (five determinants with 29 observed variables) and the result is presented in Table 3.

The result shows that, all Cronbach's Alpha coefficients of population are above 0.6; all Corrected Item - Total Correlation of observed variables are above 0.3 . So, all variables of research model are suitable for next analyses (Hair, Anderson, Tatham, \& Black, 2006).

\subsection{Exploratory Factor Analysis (EFA)}

EFA were conducted and we used the method of extracting coefficients. The results of Component Analysis and Varimax yields 29 attributes for the independent variables (see Table 4).

The results of factor analysis in Table 3 show that $0.5<\mathrm{KMO}=0.897<1$. Bartlett's testimony shows sig. $=0.000$ $<0.05$. It means variables in the whole are interrelated. After implementing the rotation matrix, five determinants with factor load factor are greater than 0.5; Eigenvalues are greater than 1 ; the variance explained is $58.346 \%$, which demonstrates that research data analyzing factor discovery is appropriate. Through the quality assurance of the scale and the test of the EFA model, we have identified five determinants influencing the perception of the selling price of luxury apartments.

\subsection{Regression Model Analysis}

Based on adjusted model after the exploratory factor analysis, we have a multiple regression model as follows:

$$
\mathrm{PSPLA}=\alpha+\beta_{1} \mathrm{PC}+\beta_{2} \mathrm{LP}+\beta_{3} \mathrm{SA}+\beta_{4} \mathrm{QS}+\beta_{5} \mathrm{DF}
$$

Results of Table 5, 6, 7 show:

Table 5: Model Summary ${ }^{b}$

\begin{tabular}{|l|l|l|l|l|}
\hline Model & $\mathbf{R}$ & $\begin{array}{c}\mathbf{R} \\
\text { Square }\end{array}$ & $\begin{array}{c}\text { Adjusted } \\
\mathbf{R} \\
\text { Square }\end{array}$ & $\begin{array}{c}\text { Std. Error of } \\
\text { the Estimate }\end{array}$ \\
\hline 1 & $.943^{\mathrm{a}}$ & .890 & .889 & .11992 \\
\hline
\end{tabular}

a. Predictors (Constant): QS, LP, SA, PC, DF

b. Dependent Variable: PSPLA

Table 6: Anova ${ }^{a}$

\begin{tabular}{|c|c|c|c|c|c|}
\hline Model & $\begin{array}{c}\text { Sum of } \\
\text { Squares }\end{array}$ & Df & $\begin{array}{c}\text { Mean } \\
\text { Square }\end{array}$ & F & Sig. \\
\hline 1 Regression & 52.495 & 5 & 10.499 & 730.087 & $.000^{\mathrm{b}}$ \\
Residual & 6.500 & 452 & .014 & & \\
Total & 58.995 & 457 & & & \\
\hline
\end{tabular}

a. Predictors (Constant): QS, LP, SA, PC, DF

b. Dependent Variable: PSPLA 
Table 7: Coefficients ${ }^{a}$

\begin{tabular}{|c|c|c|c|c|c|c|c|}
\hline \multirow[t]{2}{*}{ Model } & \multicolumn{2}{|c|}{$\begin{array}{l}\text { Unstandardized } \\
\text { Coefficients }\end{array}$} & \multirow{2}{*}{$\begin{array}{c}\begin{array}{c}\text { Standardized } \\
\text { Coefficients }\end{array} \\
\text { Beta }\end{array}$} & \multirow[t]{2}{*}{$T$} & \multirow[t]{2}{*}{ Sig. } & \multicolumn{2}{|c|}{$\begin{array}{l}\text { Collinearity } \\
\text { Statistics }\end{array}$} \\
\hline & B & Std. & & & & Tolerance & VIF \\
\hline (Constant) & .843 & .057 & & 14.726 & .000 & & \\
\hline LP & .156 & .008 & .342 & 20.641 & .000 & .890 & 1.124 \\
\hline SA & .198 & .014 & .357 & 14.630 & .000 & .410 & 2.436 \\
\hline PC & .175 & .009 & .334 & 18.627 & .000 & .757 & 1.322 \\
\hline DF & .113 & .011 & .207 & 10.609 & .000 & .638 & 1.566 \\
\hline QS & .174 & .025 & .207 & 7.151 & .000 & .292 & 3.426 \\
\hline
\end{tabular}

a. Dependent Variable: PSPLA

Multicollinearity testing. All variance inflation factors (VIF) of three independent variables are under 2.0; of these, two independent variables are under 4.0; but still allowed, so multicollinearity of model is low (Hair et al, 2009; Hoang \& $\mathrm{Chu}, 2008)$. Therefore, this regression model does not have any violation of the CLRM basic assumption.

ANOVA testing result. Level of significant (Sig.) $=0.000$ implies that multiple regression model is suitable with data. Coefficient of R2 (R Square) $=0.890$, which means $89.0 \%$ of the total variation in the perception of the selling price of luxury apartments will be explained by the regression model. Research model result indicates that all independent variables; namely Physical characteristics of a luxury apartment (PC); Location and position of an apartment (LP); Surrounding area (SA); Quality of service provided by managers (QS) and Demographics factor (DF) are significant (because Sig. $<0.05)$ to the perception $\mathrm{v}$ the selling price of luxury apartments. Determinants have influences on the perception of the selling price of luxury apartments are presented in the following standardized regression model:

$$
\text { PSPLA }=0.342 \times \mathrm{LP}+0.357 \times \mathrm{SA}+0.334 \times \mathrm{PC}+0.207
$$
$\mathrm{x} \mathrm{DF}+0.207 \times \mathrm{QS}$

Thus, five hypotheses (H1, H2, H3, H4 and H5) are accepted.

\section{Discussion}

\subsection{Physical Characteristics (PC)}

The physical characteristics of luxury apartments positively affect the perception of the selling price of the apartment. The quality of a building's exterior finishing and interior art decoration always brings a luxurious feeling to the living space. Quality of detailed planning and of highclass design will make living space in an apartment comfort and convenient. Functional rooms such as the spiritual area, kitchen, bathroom, drying area, common room, light and ventilation doors and facilities and equipment attached to the building and internal logic design will greatly enhance the user value. However, many investors have not applied modern construction technologies, the quality of fire apartments and equipment attached to the construction is not really suitable for luxury apartments.

\subsection{Surrounding Area (SA)}

This factor has the largest influence on the perception of the selling price of the apartment in Hanoi. In some luxury apartment projects, when residents move in, they reveal many inadequacies that cause uncomfortable psychology and affect their daily life quality such as: Sharing the backward and over-existing water supply and drainage system, so it is not possible to discharge sewage as well as water when it is heavy raining which causes floods and environmental pollution; lack of clean water or unqualified water; there are very few public works around the project area; infrastructure and roads are still limited, etc.

Many investors have invested in artificial landscapes and entertainment area to meet the living quality of residents, but they are surrounded by several shortcomings right from the beginning of the project. However, many luxury apartment projects have invested in a variety of trees, which have created a sense of tranquility and been close to nature. This contributes to improving the positive feeling of buyers' decision to buy a luxury apartment.

\subsection{Location and Position (LP)}

The location and position of an apartment are the second most influential factors in the research model to the perception of the selling price of the apartment. The location of the apartment with a view overlooking the landscape outside of the charming landscape, greatly impacts on the satisfaction and love of the accommodation. The position 
of the apartment also adds invisible values, making it easy for customers to decide to buy that apartment. Apartment position is also reflected in the architecture of construction, construction quality and the price of that apartment. However, many investors when implementing these luxury apartments project have not paid enough attention to some elements of an apartment such as ventilation, natural light, air circulation and spiritual values.

\subsection{Quality of Service (QS)}

The quality of service provided by the management board as well as of professional units must always satisfy and comfort their residents and customers. Beside some good quality luxury apartments projects, there are still a number of projects that are built majestically and worth hundreds of billion, but the service quality is not commensurate. Residents have repeatedly reported this amateurism and weaknesses of the building management unit to building management board and service providers.

\subsection{Demographic Factors (DF)}

This factor has a positive effect on the perception of the selling price of the apartment. The component attributes of factors are customer age, customer income, education level and number of family members. People tend to choose products that reflect their role and position in society. Buyers' decisions are also influenced by personal characteristics such as their age, occupation, economic circumstances, lifestyle, personality and notions. This factor plays a very important role in choosing which apartment segment to buy. Customers will evaluate benefits that that apartment segment brings, customers will feel satisfied and proud of the accommodation they choose and profits that customers can gain when reselling, etc. However, the inventory and dull condition of luxury apartments is due to the fact that the investor has insufficient demographic information, housing status and income level of the target customer segment.

\section{Recommendations}

\subsection{For the Physical Characteristics of Luxury Apartments}

The government should encourage investors to develop housing in general and luxury housing segment in particular through the tax policy: reduce taxes for investors to apply modern constructing technologies to reduce construction time, reduce waste, sound and heat insulation, reduce power consumption, etc. In addition, the quality of fire prevention and extinguisher equipment and facilities of the apartment should be modern and durable; investors should use high-class imported materials with high quality of exterior and interior finish. Besides, investors also need to implement many smart home technologies for buildings and apartments.

\subsection{Regarding the location and position of an apartment}

When planning and designing high-end apartment projects, investors need to pay attention to the location of each apartment, so that fresh wind and natural light can reach, to ensure the air circulation through the doors, windows or logia. These factors contribute to the highest quality improvement for each apartment. In addition, investors need to pay attention to other factors that make the building's position advantageous in terms of spiritual values, aesthetic values and quality of life.

\subsection{For Surrounding Area Factors}

The government should take the lead in mobilizing social resources to invest in public infrastructure, traffic and public works before granting licenses to enterprises to research a project. The quality of luxury apartments is highly dependent on the leadership of the government, expressed through general planning, detailed planning to achieve the goals of social security and defense vision in dozen years later. Planning must be highly feasible in terms of source and financial mechanism to quickly implement to avoid wasting land resources and opportunities for other socioeconomic development. In addition, investors also need to pay attention right from the process of implementing water supply system and clean water supply for luxury apartments.

\subsection{For Quality of Service Provided by the Manager}

Construction companies need to ensure the quality of construction as promised to investors. Investor must constantly check the project progress to ensure the quality of apartment construction as presented to customers, to minimize risks for customers. Agencies and investors need to pay special attention to the quality of human resources for the Building Management Board and professional service providers. Residents at luxury apartments who expect the quality of human resources is similar to that at 4- or 5-star hotels. In addition, it is necessary to separate the two apartment management activities and provide living space for the households; agencies and investors also need to review and improve the authorization mechanism for the Management Board. Currently, in some LAS, the management board manages $2 \%$ of the project maintenance fee, which is the cause of the security disorder in locality where the apartment project in general and luxury apartments in particular. 


\subsection{For Demographic Factors}

Investors need to collect sufficient information to conduct a broad demographic survey, housing status and source of income of the target customer segment. There is a basis for planning and making investment and business strategies of the LAS segment close to the market's consumption (avoiding sluggish inventories which can cause economic losses to investors and gloomy city environment).

\section{References}

Ajzen, I. (1991). The theory of planned Behavior. Organizational behavior and human decision processes, 50, 179-211.

Ajzen, I., \& Fishbein, M. (1975). Belief, attitude, intention, and behavior: an introduction to theory and research. Reading, MA: Addison-Wesley.

Baek, U., Sim, Y., \& Lee, S. K. (2019). Analysis of Hierarchical Competition Structure and Pricing Strategy in the Hotel Industry. Journal of Asian Finance, Economics and Business, 6(4), 179187. https://doi.org/10.13106/jafeb.2019.vol6.no4.179

Bui, P. M. (2013). Applying the position - quality theory for pricing assessment of real estate. Economy and Forecast Review (Vietnam), 20, 63-67.

Cropper, M. L., Deck, L. B., \& McConnell, K. E. (1988). On the Choice of Functional Form for Hedonic Price Functions. The Review of Economics and Statistics, 70(4), 668-675. http:// links.jstor.org/sici?sici=0034-6535\%28198811\%2970\%3A4\% 3С668\%3АOTCOFF\%3E2.0.CO\%3B2-8.

Gerlach, S., \& Wensheng, P. (2005). Bank Lending and Property price in HongKong. Journal of Banking \& Finance, 29(2), 461481. https://doi.org/10.1016/j.jbankfin.2004.05.015

Ghosh, C., Guttery, R.S., \& Sirmans, C.F. (1997). The Effects of the Real Estate Crisis on Institutional Stock Prices. Real Estate Economics, 25(4), 591-614. https://DOI: 10.1111/15406229.00729

Greenberg, M.R., \& Crossney, K.B. (2006). The changing face of public concern about pollution in the United States: A case study of New Jersey. Environmentalist, 26(4), 255 -268. https:// DOI: 10.1007/s10669-006-8662-7.

Fanning, S. F. (2005). Market Analysis for Real Estate.

Hair, J. F., Joseph, F. Jr., Anderson, R. E., Tatham, R. L., \& Black, W. C. (1998). Multivariate data analysis (5th ed.). Prentice Hall, Upper Saddle River, NJ.

Hair, J. F., Anderson, R. E., Tatham, R. L., \& Black, W. C. (2006). Multivariate data analysis. Upper Saddle River, NJ: PrenticeHall International Inc.

Hair, J. F., Black, W. C., Babin, B. J., \& Anderson, R. E. (2009). Multivariate Data Analysis (7th ed.). Upper Saddle River, NJ: Prentice Hall International.

Hinkelmann, C., \& Swidler, S. (2008). Trading House Price Risk with Existing Futures Contracts. Journal of Real Estate Finance and Economics, 36(1), 37-52. http://dx.doi.org/10.1007/ s11146-007-9075-1.

Hoang, H. P., \& Wakely, P. (2000). Status, Quality and the Other Trade-off: Towards a New Theory of Urban Residential Location. Urban studies, 37(1), 7-35. https://doi. org/10.1080/0042098002276.

Hoang, T., \& Chu, N. M. N. (2008). Analyzing researched data with SPSS ( $2^{\text {nd }}$ ed.). Ho Chi Minh City, Vietnam: Hong Duc Publishing House.

Jeon, J. H. (2018). The Impact of Asian Economic Policy Uncertainty: Evidence from Korean Housing Market. Journal of Asian Finance, Economics and Business, 5(2), 43-51. https:// doi.org/10.13106/jafeb.2018.vol5.no2.43.

Kapopoulous, P., \& Siokis, F. (2005). Stock and real estate prices in Greece: wealth versus 'credit-price' effect. Applied Economics Letters, 12(2), 125-128. https://doi.org/10.1080/135048504200 0307107.

Kim, A. M. (2007). The Impact of Social Norms in the Market Pricing of Private Property Rights in Vietnam. World Development, 35(12), 2079-2095. https://doi.org/10.1016/j. worlddev.2007.01.006.

Kotler, P. (2005). Administration of Marketing. Hanoi, Vietnam: Statistical publisher (Vietnamese).

Kuminoff, N. V., Christopher, F. P., \& Pope, J. C. (2008). Hedonic Price Functions: Guidance on Empirical Specification. Paper presented at the American Agricultural Economics Association Annual Meeting, Orlando, Florida.

Markowitz, H. (1952). Portfolio selection. Journal of Finance, 7(1), 77-91. https://doi.org/10.1111/j.1540-6261.1952.tb01525.x.

Nguyen, M. L. T., Bui, T. N., \& Nguyen, T. Q. (2019). Relationships between Real Estate Markets and Economic Growth in Vietnam. Journal of Asian Finance, Economics and Business, 6(1), 121128. http://doi.org/10.13106/jafeb.2019.vol6.no1.121

Nguyen, Q. T. (2014). Some main factors affecting decisions to buy high-quality apartments of customers in Ho Chi Minh City. Journal of Development Economics (Vietnam), 279, 92-107.

Nguyen, T. A. (2018). Study the impact of financial and nonfinancial factors on the choice of buying low- and mediumpriced housing ( $\mathrm{PhD}$ thesis). The Vietnam National University, Hanoi, Vietnam.

Özdilek, U., Canonne, J., \& Besner, C. (2009). Les determinants de la valeur marchande des proprietes residentielles unifamiliales de l'ile de Montreal: Evaluation de masse conjuguee aux SIG. Canadian Journal of Administrative Sciences, 19(4) 369-384. https://doi.org/10.1111/j.1936-4490.2002.tb00282.x.

Qiuxue, L., \& James, T. P. J. (2013). Influences on the buying behavior of purchasing commercial housing in Nanning city of Guangxi province, China. Journal of management and Marketing research, 12, 1-11.

Seetharaman, A., Saravanan, A. S., Patwa, N., \& Bey, J. M. (2017). The Impact of Property Management Services on Tenants' Satisfaction with Industrial Buildings. Journal of Asian 
Finance, Economics and Business, 4(3), 57-73. http://dx.doi. org/10.13106/jafeb.2017.vol4.no3.57

Selim, S. (2008). Determinants of house prices in Turkey: A Hedonic regression model. Doğuş Üniversitesi Dergisi, 9(1), 65-76.

Sergio, B., Jorge, N., \& Bernardo, M. (2002). Economics of Air Pollution: Hedonic Price Model and Smell Consequences of Sewage Treatment Plants in Urban Areas. Economic of Air Pollution, 234, 1-25.

Sheppard, S. C., \& Cheshire, P. (1995). On the Price of Land and the Value of Amenities. Economica, 62(246), 247-67. DOI: $10.2307 / 2554906$.

Solomon, M., Bamossy, G., Akegaard, S., \& Hogg. M. K. (2006). Consumer behavior a European perspective, (3rd ed.). London, United Kingdom: Pearson Education Limited.
Vukina, T., \& Wossink, A. (2000). Environmental Policies and Agricultural Land Values: Evidence from the Dutch Nutrient Quota System. Land Economics, 76(3), 413-429. DOI: 10.2307/3147038.

Wang, D., \& Li, S. M. (2006). Socioeconomic differentials and stated housing preferences in Guangzhou, China. Habitat International, 30(2), 305-326. https://doi.org/10.1016/j. habitatint.2004.02.009.

Yusuf, A. A., \& Resosudarmo, B.P. (2009). Does clean air matter in developing countries' megacities? A hedonic price analysis of the Jakarta housing market, Indonesia. Ecological economics, 68(5), 1398 - 1407. https://doi.org/10.1016/j.ecolecon.2008.09.011.

Zeng, R. (2013). Attributes influencing home buyers' purchase decisions: a quantitative study of the Wuhan residential housing market (Doctor of Business Administration (DBA) thesis). Southern Cross University, Lismore, NSW, Australia. 